Ю. М. Колесник, М. О. Авраменко, С. А. Моргунцова, О. А. Рижов Запорізький державний медичний університет

\title{
СТРАТЕГІЯ ВПРОВАДЖЕННЯ КУРСІВ ЗА ВИБОРОМ НА БАЗІ ТЕХНОЛОГІЇ ОНЛАЙН-КУРСІВ НА ПЛАТФОРМІ еdХ
}

\author{
Yu. M. Kolesnyk, M. O. Avramenko, S. A. Morhuntsova, O. A. Ryzhov \\ Zaporozhye State Medical University \\ STRATEGY OF IMPLEMENTATION ELECTIVE ONLINE COURSES \\ BASED ON OPEN EdX PLATFORM
}

\begin{abstract}
У статті розкрита послідовна стратегія впровадження в медичному університеті курсів за вибором на базі технології дистанційного навчання у вигляді онлайн-курсів. Показано, що успішне впровадження онлайн-курсів можливо при наявності таких складових, як: готовність викладацького складу до опанування нових технологій навчання та зміни своєї ролі в навчальному процесі; готовність студентів до використання дистанційних технологій навчання; наявність інфраструктури в університеті, яка забезпечує сервіси дистанційного навчання; наявність системи перевірки якості контенту онлайн-курсів, які розробляються. Особлива увага звертається на необхідність зміни структури навчального процесу та ролі викладачів при впровадженні онлайнкурсів. Авторами обгрунтовано вибір платформи для розробки онлайн-курсів Open edX за критеріями.
\end{abstract}

Ключові слова: медична освіта; дистанційне навчання; онлайн-курси; LMS edX; MS Azure; хмарні сервіси IT.

A sequential strategy of implementation elective online courses at medical university on the basis of distance learning technology is revealed in the article. It is shown that successful implementation of online courses is possible in the presence of such components as academic staff readiness to develop new learning technologies and the acceptance of the fact of their changing role in the educational process; students' readiness to use distance learning technologies; availability of infrastructure at university that provides distance learning services; presence of a quality assurance system for courses content. Particular attention is paid to the need to change the structural organization of the educational process and the role of instructors in the implementation process. The authors substantiated their choice of the Open edX platform for online courses development based on some criteria.

Key words: medical education; distance learning; online courses; LMS edX; MS Azure; cloud services IT.

Вступ. У Законі України “Про вищу освіту” [1] знайшли імплементацію два базових положення інформаційного суспільства, це доступ до інформації та свобода самореалізації людини в поняттях “академічна свобода” та “академічна мобільність”. У рамках академічної свободи студент повинен мати можливість самостійно формувати частину навчальної програми, формувати траєкторію навчального процесу, відповідно до своїх професійних інтересів. Академічна мобільність дозволяє паралельно проходити навчання або стажування в іншому навчальному закладі. В існуючій організаційній структурі та традиціях навчання ВМ(Ф)НЗ України зробити це практично неможливо. Відкритий доступ до інформації є характерною рисою інформаційного суспільства, і наші студенти мають доступ до широкого інформаційного поля у будь-який час та практично у будь-якому місці. Медичні університети, маючи консервативну організацію навчального процесу, на цей час не забезпечують або забезпечують формаль- но академічну свободу та мобільність своїх студентів. Кожна клінічна кафедра стоїть перед дилемою, як забезпечити високий рівень професійної компетентності майбутнього лікаря, яку можна сформувати тільки “біля ліжка хворого” та самостійним навчанням студента за технологіями дистанційного навчання епохи інформаційного суспільства.

Аналізуючи протиріччя між традиційною системою організації навчального процесу та інноваційними комп’ютерними технологіями навчання, які $є$ чужими для стереотипу мислення викладача медичного університету, ми повинні спиратись на історичні та філософські закони розвитку суспільства. Кожен істотний крок розвитку суспільства був пов'язаний зі зміною засобів обробки та передачі інформації у цьому суспільстві. Але завжди носієм професійних знань та компетенцій був і є фахівець, у тому числі і в інформаційному суспільстві. Ми знімаємо це протиріччя, коли інформаційні технології починаємо розглядати як більш ефективний 
інструмент досягнення освітніх цілей, доступом до яких вже володіють наші студенти.

Стрімкий розвиток технологій дистанційного навчання та формування інфраструктури 3G, активне використання мобільних пристроїв студентами створюють умови для імплементації цих технологій у навчальний процес ВМ(Ф)НЗ. Аналіз навчального плану і програм навчальних дисциплін системи медичної освіти показав, що саме “курси за вибором”, з позицій організації навчального процесу та дидактики викладання, найбільш адаптовані до змішаної або дистанційної форми навчання.

Мета роботи - запропонувати стратегію впровадження в навчальний процес ВМ(Ф)НЗ курсів за вибором за формою дистанційного навчання за технологією онлайн-курсів, які реалізовані на платформі edX, розташованій на віртуальному сервері хмари Azure.

Основна частина. Впровадження інформаційно-комунікативних технологій (IKT) навчання в освітній процес дозволяє знайти шляхи для вирішення питання надання, значною мірою, студентам академічної свободи та мобільності. IКТ розширюють освітній простір вищого навчального закладу та дозволяють залучати провідних спеціалістів 3 інших навчальних і дослідницьких установ для навчання студентів, інтернів та підвищення кваліфікації професорсько-викладацького складу. Але у разі широкого впровадження в навчальний процес курсів за вибором, у форматі онлайн-курсів, треба правильно вибрати технологію дистанційного навчання, яку можна ефективно реалізувати саме в медичному університеті. Інтенсивний розвиток інтернет-технологій надає цілий спектр різноманітних інструментів розміщення та доставки навчального матеріалу, інтерактивної взаємодії студента та викладача в режимах онлайн та оффлайн, створення систем моніторингу за навчальною діяльністю студента, що формує умови для розробки та застосування різних технологій дистанційного навчання студентів. Проведений аналіз таких технологій за критеріями доступності та ефективності показав, що технологія змішаного навчання (blended learning) [2] найбільш відповідає особливостям організації навчального процесу і рівню IКТ-компетенцій студентів та викладачів ЗДМУ.

Педагогічні технології змішаного навчання дозволяють використати мобільність, адаптивність, гнучкість дистанційного навчання з перевагами традиційної форми організації навчального про- цесу [2]. В даний час є багато моделей та форматів змішаного навчання, такі, як модель ротації, flex модель, self-blend модель, метод перевернутого навчання та інші [3]. Ми розглядаємо модель змішаного навчання як цілеспрямований навчальний процес, який поєднує методики традиційного аудиторного навчання з викладачем із технологіями дистанційного навчання, де частка аудиторного навчання складає 10-30 \%, відповідно, дистанційне - 70-90 \%, метою якого є формування професійних компетенцій відповідно до об'єму робочих навчальних програм, дисциплін, що вивчаються.

Системне впровадження дистанційної форми навчання в медичному університеті потребує вирішення ряду питань: як створити контент онлайнкурсів; як забезпечити WiFi-доступ до якісного Інтернету з мобільних пристроїв; як пристосувати педагогічну систему ВМ $(\Phi) Н 3$ до нової форми навчання? Нами були розроблені послідовні кроки реалізації стратегії впровадження онлайн-курсів у навчальний процес медичного університету.

1. Формування готовності професорсько-педагогічного складу університету до зміни педагогічної системи організації навчального процесу з ряду курсів, відповідно до потреб дистанційної форми навчання.

2. Внесення змін до навчальних планів.

3. Розробка нормативної бази з проведення курсів онлайн за технологією змішаного навчання.

4. Вибір платформи LMS (Learning Management System) для розробки та супроводу онлайн-курсів у навчальний процес ВМ(Ф)НЗ.

5. Створення інфраструктури університету для організації онлайн-навчання, зокрема ряд майданчиків із якісним високошвидкісним WiFi-доступом до Інтернету.

6. Партнерство з провайдерами хмарних сервісів.

7. Організація масштабного навчання викладачів технологій розробки онлайн-курсів та організації дистанційного навчання.

8. Створення системи контролю якості онлайнкурсів, які розробляються на кафедрах.

9. Розробка плану залучення студентів до нової форми навчання та його реалізація.

10. Розробка довготривалої програми імплементації та супроводу онлайн-курсів до системи медичної освіти вищого навчального закладу.

Впровадження онлайн-курсів, як основної форми проведення курсів за вибором в університеті, потребує з'ясувати готовність учасників навчального 
процесу до активного застосування комп’ютерних технологій та технологій дистанційного навчання. В ЗДМУ інформатизація навчального процесу планово проводиться з 2003 року, відповідно до концепції інформатизації, яка переробляється кожні 3-5 років [4, 5]. Такий підхід дозволив створити єдиний інформаційний простір університету, який забезпечує оптимальні умови для організації навчання студентів та забезпечення навчально-методичними матеріалами. Обладнання лекційних аудиторій технічними засобами для презентацій лекційного матеріалу та проведення відеоконференцій формують у професорсько-викладацького складу певний рівень IKT-компетенцій. Тому використання нової форми організації навчального процесу у форматі змішаного навчання розглядається адміністрацією університету як новий рівень навичок та вмінь, який відповідає потребам сьогодення.

Впровадження навчання на відстані зумовлює докорінну зміну ролі викладача. Викладач стає “наставником-консультантом, який повинен координувати пізнавальний процес, постійно вдосконалювати курси, які він викладає, підвищувати творчу активність і кваліфікацію відповідно до нововведень та інновацій” [6].

Проведений системний структурно-функціональний аналіз педагогічної системи кафедри, яка активно використовує в навчальному процесі IKT i впроваджує дистанційну форму навчання, дав змогу відокремити три основних ролі для викладачів, які повинні бути реалізовані на кафедрі, це: викладач-методист, викладач-тьютор, викладачдизайнер онлайн-курсів [7].

Викладач-методист виконує основну організаційну та методичну функції щодо формування вимог до онлайн-курсу, відповідно до цілей робочої програми з навчальної дисципліни, розробки змістової складової та сценарію онлайн-курсу, складання плану розробки курсу, педагогічних технологій організації навчання студентів.

Викладач-дизайнер онлайн-курсів має функції, які реалізуються засобами платформи розробки та супроводу онлайн-курсів: розробка сценаріїв відповідно до рекомендацій викладача-методиста; створення або редагування бази навчальних елементів (графіка, презентації, відео, текстові фрагменти); створення або редагування бази тестових завдань; розробка сценаріїв авторських курсів, які відображають особисті дидактичні підходи викладачів до організації навчання.
Основна функція викладача-тьютора - супровід процесу персоніфікованого навчання студента засобами моніторингу платформи онлайн-курсів, організація інтерактивної взаємодії зі студентами у форматі семінарів, консультацій, лабораторних занять засобами інтернет-сервісів (блог, чат, відеоконференція тощо) у єдиному освітньому середовищі ВНЗ.

Для успішного впровадження нових ролей та функцій викладачів у навчальному процесі кафедри університету потрібна мотивація та системна підготовка на курсах тематичного удосконалення відповідного профілю. Важливим елементом сталого розвитку процесу імплементації онлайн-курсів $є$ розробка нормативної бази системи дистанційної освіти та реструктуризації навчальних планів відповідно до нових форм і технологій проведення навчального процесу.

Гармонізація Положення про дистанційне навчання відповідно до навчальних цілей, інфраструктури університету, рівня IKT-компетенцій викладачів, з урахуванням відповідальності підрозділів університету, які супроводжують інформаційно-комунікаційну структуру та програмне забезпечення навчального процесу, забезпечує прозорість і стабільність навчального процесу, організованого на базі технологій онлайн-курсів.

Після прийняття обгрунтованого рішення застосування технологій дистанційної освіти для організації навчального процесу з курсів за вибором важливим рішенням є вибір платформи LMS для розробки та супроводу онлайн-курсів. Нами був проведений порівняльний аналіз OpenSource платформ, таких, як Moodle, edX, Coursera та ін., 3 критеріїв надійності, простоти інтерфейсу дизайнера онлайн-курсів та студента, який навчається, супроводу сервера платформи LMS, наявності практики розгортання серверів у хмарі, кількості користувачів онлайн-курсів на відповідній платформі. Результати аналізу показали, що найбільш відповідає заданим критеріям платформа edX [8], яка була розроблена співробітниками Массачусетського технологічного інституту сумісно з Гарвардським університетом і впроваджена у 2012 році. В даний час вона використовується як безкоштовна інтернет-платформа масових відкритих онлайнкурсів (МВOK, MOOC (анг.). Привабливим є те, що розробниками, з самого початку розробки та впровадження цієї платформи, було орієнтування на хмарні технології. Розміщення сервера в хмарі, 
по-перше, є важливим аргументом для медичних університетів, де обмаль кваліфікованого технічного персоналу для супроводу IT-систем; по-друге, спрощує процес масштабування рішення при збільшенні кількості онлайн-курсів та студентів, які навчаються. Аналізуючи провайдерів хмарних сервісів для розміщення платформи еdX, які доступні в Україні, їх можливості, вартість оренди, наявність академічних програм, ми обрали хмару Microsoft Azure. На даний час Microsoft має готові рішення інтеграції програмних сервісів MS Office 3653 платформою edX, яка розміщена в хмарі MS Azure. Реєстрація професорсько-викладацького складу та студентів університету в хмарному сервісі Active Directory дозволяє реалізувати інфраструктурне рішення, яке інтегрує ряд корпоративних та персональних функцій інформаційного забезпечення навчального процесу, а саме: система електронного документообігу на рівні кафедри або університету, який розгорнутий у MS SharePoint; засоби корпоративної комунікації: е-пошта на базі Exchange, Skype for Bussiness; блог на базі Yammer; для персональних користувачів; пакет програм MS Office 365; автоматична реєстрація на платформі edX.

На першому етапі впровадження edX важливе значення має відкритість цієї системи для навчання. Дизайнери онлайн-курсів мають можливість пройти навчання, зареєструвавшись на сайтах http://www. edx.org/ англійською або українською мовою, на сайті http://prometheus.org.ua/. В ЗДМУ була розроблена програма курсу тематичного удосконалення (ТУ) “Технологія розробки онлайн-курсів на платформі edX” для викладачів університету. На базі цієї програми було проведено навчання викладачів з 61 кафедри університету та розроблено 68 онлайнкурсів.

Система перевірки якості розроблених в університеті онлайн-курсів є обов'язковим компонентом навчально-методичного комплексу онлайн-курсів в університеті (системи дистанційного навчання). В ЗДМУ при Центральній методичній раді університету була створена експертна комісія (група) під керівництвом проректора з науково-педагогічної та навчальної роботи, метою якої є аналіз онлайн-курсу за критеріями якості. До складу комісії були залучені провідні фахівці клінічних, фармацевтичних і загальнотеоретичних кафедр, а також представники

\section{Список літератури}

1. Про вищу освіту : Закон України від 01.07.14 № 1556-VII. бібліотеки університету. Аналіз курсів відбувався за розробленими критеріями, які було розподілено між експертами відповідно до профілю кафедр. До положення оцінки якості онлайн-курсів були залучені наступні критерії: група структурно цільових показників відповідності змісту онлайн-курсу робочій програмі навчальної дисципліни; показники, що характеризують якість контенту; група показників інформаційно-методичного й організаційного забезпечення; показники, які характеризують систему контролю знань у процесі навчання студента; група дизайн-ергономічних показників; група програмнотехнічних показників. Таким чином, детальний аналіз онлайн-курсу, який був розроблений фахівцями кафедр, дозволяє виявити недоліки та відправити курс на доробку. Зворотний зв’ язок із кафедрою на етапі доведення онлайн-курсу до відповідних стандартів якості розглядається нами як пролонгований етап навчання викладачів.

Робота студентів з онлайн-курсами перш за все розрахована на те, що вони мають відповідний рівень ІТ-компетенцій та використовують для роботи 3 контентом персональні мобільні пристрої (нетбуки, планшети, смартфони тощо). Нами було проведено анкетування студентів з приводу готовності їх до навчання у форматі змішаного навчання. За забезпеченістю персональними мобільними пристроями - 97 \% студентів мають таку можливість; 89,2 \% студентів відмітили, що у них достатньо навичок для роботи з комп'ютерними засобами навчання; 84 \% 3 них відмітили, що основним пристроєм для роботи 3 онлайн-курсом є домашній планшет; 81 \% студентів відмітили, що реєстрацію на курс вони зробили самостійно; 87,6 \% студентів відмітили, що у них є можливість спілкуватись із викладачем; 68,8 \% студентів позитивно ставляться до дистанційної форми навчання на базі онлайн-курсів. Таким чином, проведене анкетування показало позитивне ставлення студентів до нової форми навчання і володіння навичками роботи з комп’ютерними засобами навчання.

Висновок. Системний підхід до розробки стратегії впровадження онлайн-курсів у навчальний процес студентів медичного університету дозволяє вирішити складну задачу створення інфраструктури дистанційного навчання на базі хмарних технологій, розробки онлайн-курсів та початку навчання студентів у системі додипломної освіти.

2. Теорія та практика змішаного навчання : монографія / [В. М. Кухаренко, С. М. Березенська, К. Л. Бугай- 
чук, Н. Ю. Олійник та ін.]. - Х. : Міськдрук, НТУ “ХПІ”, 2016. - 284 с.

3. Бугайчук К. Л. Змішане навчання: теоретичний аналіз та стратегія впровадження в освітній процес вищих навчальних закладів / К. Л. Бугайчук // Інформаційні технології і засоби навчання. - 2016. - Т. 54, № 4. - С. 1-15.

4. Колесник Ю. М. Концепція розвитку дистанційного навчання у Запорізькому державному медичному університеті / Ю. М. Колесник, О. А. Рижов // Актуальні питання фармацевтичної і медичної науки та практики. Збірник наукових статей. Випуск XVIII. - Запоріжжя : Вид-во ЗДМУ, 2007. - С. 11-21.

5. Колесник Ю. М. Концепція інформатизації медичних навчальних закладів / Ю. М. Колесник, О. А. Рижов // Актуальні питання фармацевтичної і медичної науки та практики. Додаток : Тези доповідей Всеукраїнської науково-методичної відеоконференції з міжнародною участю

\section{References}

1. Zakon Ukrainy «Pro vyshchu osvitu» vid 01.07.14 №1556-VII (2014). [The Higher Education Act of Ukraine of 01.07.14 №1556-VII] [in Ukrainian].

2. Kukharenko, V.M., Berezenska, S.M., Buhaichuk, K.L., Oliinyk, N.Yu., \& oth. (2016). Teoriia ta praktyka zmishanoho navchannia: monohrafiia [Theory and practice of blended learning: monography]. Kharkiv: «Miskdruk», NTU «KhPI» [in Ukrainian].

3. Buhaichuk, K.L. (2016). Zmishane navchannia: teoretychnyi analiz ta stratehiia vprovadzhennia v osvitnii protses vyshchykh navchalnykh zakladiv [Blended learning: theoretical analysis and strategy for implementation into educational process of higher educational institutions]. Informatsiini tekhnolohii i zasoby navchannia - Information technologies and training resources, 54 (4), 1-15 [in Ukrainian].

4. Kolesnyk, Yu.M., \& Ryzhov, O.A. (2007). Kontseptsiia rozvytku dystantsiinoho navchannia u Zaporizkomu derzhavnomu medychnomu universyteti [Distance learning at Zaporizhzhia State Medical University development concept]. Aktualni pytannia farmatsevtychnoi ta medychnoi nauky ta praktyky. Zbirnyk naukovykh statei - Current issues of pharmaceutical and medical science and practice. Collection of studies. Zaporizhzhia: Vyd-vo ZDMU, XVIII, 11-21 [in Ukrainian].

5. Kolesnyk, Yu.M., \& Ryzhov, O. A. (2013). Kontseptsiia informatyzatsii medychnykh navchalnykh zakladiv [Informational support of medical educational institutions conception]. Aktualni pytannia farmatsevtychnoi i medychnoi nauky ta praktyky: Dodatok: Tezy dopovidei Vseukrainskoi naukovo-metodychnoi videokonferentsii z mizhnarodnoiu
“Актуальні питання дистанційної освіти та телемедицини 2013”, 10-11 жовтня 2013 р. - 2013. - № 3. - С. 1-2.

6. Мінцер О. П. Роль інформаційних технологій на етапах реформування медичної освіти / О. П. Мінцер // Впровадження кредитно-модульної системи організації навчального процесу у ВМ(Ф)НЗ України: результати, проблеми та перспективи : матеріали Всеукр. навч.наук. конф. з міжнар. участю (Тернопіль, 20-21 травня 2010 р.). - Тернопіль : Укрмедкнига, 2010. - С. 246-247.

7. Рижов О. А. Структурно-функціональна модель педагогічної системи кафедри медичного навчального закладу із застосуванням автоматизованої навчальної системи / О. А. Рижов, В. В. Васілакін // Медицинская информатика и инженерия. - 2009. - № 4. - С. 88-94.

8. Gilbert M.A. edX E-Learning Course Development / Matthew A. Gilbert. - Birmingham B3 2PB, UK: Packt Publishing, 2015.

uchastiu «Aktualni pytannia dystantsiinoi osvity ta telemedytsyny 2013» 10-11 zhovtnia 2013 r. - Current issues of pharmaceutical and medical science and practice. Appendix: notes for the statement at all-Ukrainian scientific and methodological videoconference with international participation «Current issues of distance learning and telemedicine 2013», October 10-11, 2013, 3, 1-2 [in Ukrainian].

6. Mintser, O.P. (2010). Rol informatsiinykh tekhnolohii na etapakh reformuvannia medychnoi osvity [The role of information technologies on the stages of medical education reformation]. Vprovadzhennia kredytno-modulnoi systemy orhanizatsii navchalnoho protsesu u VM(F)NZ Ukrainy: rezultaty, problemy ta perspektyvy : mat-ly Vseukrainskoi navchalno-naukovoi konferentsii z mizhnarodnoiu uchastiu 20-21 travnia 2010 r. - Implementation of credit-unit system of educational process organization at $\mathrm{HM}(\mathrm{Ph}) \mathrm{EI}$ of Ukraine: results, problems and prospects: material of all-Ukrainian educational and scientific conference with international participation, May 20-21, 2010. Ternopil: Ukrmedknyha [in Ukrainian].

7. Ryzhov, O.A., \& Vasilakin, V.V. (2009). Strukturnofunktsionalna model pedahohichnoi systemy kafedry medychnoho navchalnoho zakladu iz zastosuvanniam avtomatyzovanoi navchalnoi systemy [Structural and functional model of pedagogical system of department at medical educational institution using computer-equipped learning system]. Meditsynskaya informatika i inzheneriya - Medical informatics and engineering, 4, 88-94 [in Ukrainian].

8. Gilbert, M.A. (2015). edX E-Learning Course Development. Birmingham B3 2PB, UK: Packt Publishing.

Отримано 03.04.17 